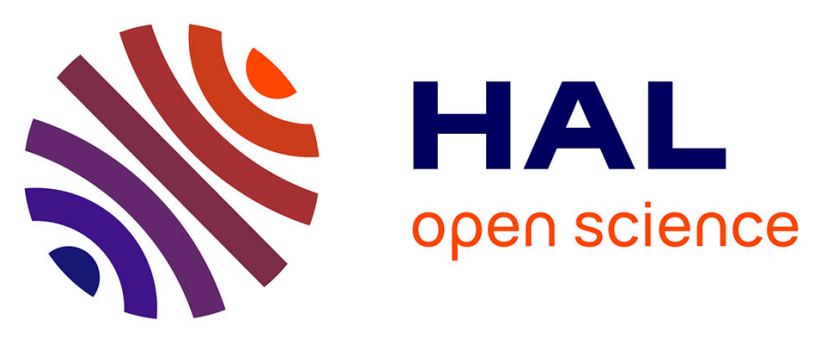

\title{
Pasireotide: A potential therapeutic alternative for resistant prolactinoma
}

Hélène Lasolle, Alexandre Vasiljevic, Françoise Borson-Chazot, Gerald Raverot

\section{To cite this version:}

Hélène Lasolle, Alexandre Vasiljevic, Françoise Borson-Chazot, Gerald Raverot. Pasireotide: A potential therapeutic alternative for resistant prolactinoma. Annales d'Endocrinologie, 2019, 80, pp.84 - 88. 10.1016/j.ando.2018.07.013 . hal-03486677

\section{HAL Id: hal-03486677 https://hal.science/hal-03486677}

Submitted on 20 Dec 2021

HAL is a multi-disciplinary open access archive for the deposit and dissemination of scientific research documents, whether they are published or not. The documents may come from teaching and research institutions in France or abroad, or from public or private research centers.
L'archive ouverte pluridisciplinaire HAL, est destinée au dépôt et à la diffusion de documents scientifiques de niveau recherche, publiés ou non, émanant des établissements d'enseignement et de recherche français ou étrangers, des laboratoires publics ou privés.

\section{다)(1) $(5$}

Distributed under a Creative Commons Attribution - NonCommerciall 4.0 International 


\section{Pasireotide: A potential therapeutic alternative for resistant prolactinoma Pasiréotide, une alternative thérapeutique pour les prolactinomes résistants ?}

Hélène Lasolle 1,2,3, Alexandre Vasiljevic, ${ }^{2,3,4}$ Françoise Borson-Chazot ${ }^{1,2}$; Gerald Raverot. $^{1,2,3}$

1 Fédération d'Endocrinologie, Centre de Référence Maladies Rares Hypophysaires HYPO, Groupement Hospitalier Est, Hospices Civils de Lyon, Bron, F-69677, France

2 Faculté de Médecine Lyon Est, Université Lyon 1, Lyon, F-69372, France

3 INSERM U1052; CNRS UMR5286; Cancer Research Centre of Lyon, Lyon, F-69372, France

4 Centre de Pathologie et de Neuropathologie Est, Groupement Hospitalier Est, Hospices Civils de Lyon, Bron, F-69677, France

Short title: pasireotide and prolactin pituitary tumor

\section{Corresponding author:}

Professor Gérald Raverot, MD, PhD

Fédération d'Endocrinologie, Groupement Hospitalier Est

Centre de Référence Maladies Rares Hypophysaires HYPO

Hôpital Louis Pradel-1er étage

59 Bd Pinel, 69677 Bron cedex France

gerald.raverot@chu-lyon.r

Word count: 2077

Number of tables: 0 , and figures: 2

Disclosure summary: The authors have nothing to disclose. 


\section{Abstract}

Context: About $10 \%$ of prolactinomas are resistant to dopamine agonists (DAs). The only alternatives for tumor and prolactin control are surgery or radiotherapy. While studies on first-generation somatostatin analogs have shown no efficacy against prolactinomas, no study has been conducted on the new multireceptor-targeted somatostatin receptor ligand pasireotide, which presents high affinity for 5, 3, 2 and 1 receptor subtypes.

Case description: A 41 year-old woman presented with a macroprolactinoma showing resistance to all available DAs. She was first diagnosed at 17 years old after which she had undergone two incomplete debulking surgeries. Under pasireotide long-acting release (LAR) treatment, plasma prolactin levels normalized and symptoms disappeared within one month after initiation. The clinical benefits of the monotherapy (specifically, prolactin levels within normal range and stable tumor volume) were maintained for seven years. Glucose tolerance was satisfactory. Pathological analysis of the tumor revealed high SSTR5 and low SSTR2 expression ( 25 and $5 \%$ of cells respectively).

Conclusion: This is a promising first report of a patient with a DA-resistant macroprolactinoma who achieved long-term control, in terms of prolactin normalization and tumor volume, under pasireotide treatment alone. Pasireotide could thus be an alternative in prolactinomas resistant to DA. SSTR expression analysis on pathology could guide patient selection.

Keywords: Pituitary tumor, prolactinoma, aggressive tumor, somatostatin receptor, pasireotide

\section{Résumé}

Contexte: Dix pour cent des prolactinomes sont résistants aux agonistes dopaminergiques (DAs), offrant comme seules possibilités thérapeutiques, pour contrôler la tumeur et la prolactinémie, la chirurgie ou la radiothérapie. Alors que les analogues de la somatostatine de première génération n'ont pas montré d'efficacité, aucune publication ne rapporte l'effet du pasiréotide, analogue de la somatostatine de nouvelle génération présentant un profil d'affinités plus large, notamment pour les récepteurs des sous-types 5, 3, 2 et 1 .

Description: Une patiente âgée de 41 ans a été adressée pour un macroprolactinome évoluant depuis l'âge de 17 ans, résistant aux agonistes dopaminergiques, ayant nécessité deux chirurgies d'exérèse incomplète. Après introduction de pasiréotide longue durée d'action (LAR), la prolactinémie s'est normalisée en 1 mois, permettant une disparition des symptômes. L'effet thérapeutique était maintenu au dernier suivi, 7 ans après l'introduction, avec une stabilisation du volume tumoral et une prolactinémie normale. La tolérance glucidique était correcte. L'analyse histologique de la tumeur a retrouvé une forte expression de SSTR5 associée à une faible expression de SSTR2 (25 et $5 \%$ des cellules respectivement).

Conclusion : Nous rapportons le premier cas de macroprolactinome résistant aux agonistes dopaminergiques, pour lequel un traitement par pasiréotide seul a permis un contrôle de la prolactinémie et du volume tumoral sur le long terme. Ainsi, le pasiréotide pourrait être une alternative thérapeutique dans les prolactinomes 
49 résistant aux agonistes dopaminergiques. L'analyse histologique de l'expression de 50 SSTR pourrait aider à sélectionner les patients.

51

52

Mots-clés : Tumeur hypophysaire, prolactinome, tumeur agressive, récepteurs à la 53 somatostatine, pasiréotide

54

55

56

57 
Prolactinomas are the most frequently encountered pituitary tumor, representing around $50 \%$ of all pituitary tumors. Dopamine-agonist (DA) therapy, especially carbegoline, is the first-line treatment and is able to normalize prolactin levels and tumor volume in most

62

cases. However, prolactin levels cannot be normalized by conventional doses in around $10 \%$ of prolactinomas [1]. These are considered as DA-"resistant" and present more often as invasive macroadenomas [2]. A tumor size reduction less than $50 \%$ maximal diameter is more rarely used as a criterion of resistance. In cases of resistance, or more rarely of intolerance to dopamine-agonists, alternative treatments are surgery and radiotherapy. However, they may not be indicated, depending on the size, localization and firmness of the tumor. Moreover, surgical excision is not always curative, especially in case of invasive tumors, while radiotherapy exposes to side effects such as hypopituitarism.

The new multireceptor-targeted somatostatin transmembrane receptor (SSTR) ligand pasireotide is marketed for patients with acromegaly or Cushing's disease. It can bind to Gprotein coupled SSTRs of normal or neoplastic pituitary cells and inhibits hormone secretion and cell growth. Unlike first generation somatostatin analogs (lanreotide or octreotide) which bind preferentially SSTR2, pasireotide binds to multiple SSTRs with a high affinity for SSTR5 followed by SSTR2, SSTR3, and SSTR1[3].

We report here the first patient with a DA-resistant macroprolactinoma to present long-term prolactin normalization on pasireotide treatment alone. 


\section{Case-report}

In 2010, a 41-year-old woman was referred to us for treatment of a DA-resistant macroprolactinoma.

She was diagnosed in 1986 with a macroprolatinoma measuring $15 \mathrm{~mm}$ and responsible for galactorrhea and amenorrhea. Initial plasma prolactin levels were $116 \mathrm{ng} / \mathrm{mL}$. The pituitary and visual function assessment were normal. Bromocriptine therapy was progressively increased up to $15 \mathrm{mg} /$ day. In the absence of control over plasma prolactin levels, surgical removal of the tumor was decided five years later in 1991. The pathological examination revealed a grade $2 \mathrm{~b}$ pituitary neuroendocrine tumor (Fig. 1A) with $100 \%$ of cells expressing prolactin (Fig.1B), high mitotic count ( $\mathrm{n}=4$ ), and positive P53 expression. Ki67 index was not interpretable because of technical issues.

After an initial period of post-operative remission, her initial symptoms recurred one year after surgery. At this point, plasma prolactin levels had risen to $94 \mathrm{ng} / \mathrm{mL}$ and a CT-scan revealed a macroadenoma measuring $20 \mathrm{~mm}$ in the right sellar region. Bromocriptine $(25 \mathrm{mg}$ per day) and quinagolide ( $225 \mu \mathrm{g}$ per day) separately failed to normalize plasma prolactin levels. A second partial surgery was required in 2003 to treat a third cranial nerve palsy caused by tumor regrowth that had occurred once DA had been stopped. Cabergoline treatment permitted a temporary and incomplete decrease in plasma prolactin levels which allowed a spontaneous pregnancy in 2007. The patient gave birth to a normal girl but menstruation was not restored despite a continued and intensified treatment with cabergoline up to $4.5 \mathrm{mg}$ per week. Plasma prolactin levels rose to $127 \mathrm{ng} / \mathrm{mL}$ while MRI showed global stability of the large right sellar residue measuring $33 \mathrm{~mm}$. Moreover, this higher dose of cabergoline was badly tolerated inducing asthenia and dizziness. Radiotherapy was then proposed but refused by the patient. 
Re-examination of the tumor fragment from the first surgery showed expression of 105 SSTR5 in 25\% of cells (Fig.1C) whereas only 5\% expressed SSTR2 (Fig.1D). The analysis of 106 genes AIP and MEN1 revealed no mutation. As part of a clinical trial (ClinicalTrials.gov Identifier: NCT00958841, approved by ethical committee of Hospices Civils de Lyon), pasireotide LAR was begun in October 2010 109 at $60 \mathrm{mg}$ every 28 days. This normalized plasma prolactin levels within one month (Fig. 2)

110 and allowed the stopping of cabergoline three months later. At this point, amenorrhea111 galactorrhea had stopped and MRI revealed a global stability of tumor size with necrotic transformation suggestive for an anti-tumor effect (Fig. 2). The treatment was well tolerated

113 without any digestive disorders. There was no diabetes mellitus, but glucose intolerance 114 occurred as shown by HbA1C rising from 5.7\% to $6.2 \%$ and fasting plasma glucose level 115 from 0.90 to $1.20 \mathrm{~g} / \mathrm{L}$ then to $1.27 \mathrm{~g} / \mathrm{L}$ six months after pasireotide initiation. However, this required no pharmacological treatment and the implementation of dietary measures was

117 sufficient.

118 Treatment was progressively decreased to $20 \mathrm{mg}$ every five weeks. At the last follow-up 119 seven years after pasireotide initiation, the plasma prolactin levels were maintained within the 120 normal range and MRI showed a stable residual tumor. Tolerance was correct, fasting plasma 121 glucose was $0.97 \mathrm{~g} / \mathrm{L}$ and $\mathrm{HbA} 1 \mathrm{c}$ was $5.7 \%$. 


\section{$\underline{\text { Discussion }}$}

We report here the first case of a DA-resistant macroprolactinoma demonstrating a clinical and hormonal response to pasireotide treatment allowing its long-term control.

Pasireotide is a new somatostatin receptor ligand currently prescribed in patients with acromegaly, Cushing's disease and neuroendocrine tumors. Compared to lanreotide and octreotide, it has a broader binding profile and significantly higher in vitro affinity for SSTR 1, 3 and 5 receptors (respectively 30, 5 and 40 times), and a lower one for SSTR 2 receptors (2.5 times) [3].

The expression of somatostatin receptor subtypes has already been described in human prolactinomas [4-6] and in light of our results presented here, may justify the potential use of somatostatin analogs in the treatment of prolactinomas. Both immunohistochemistry studies, via use of a scoring system (associating \% of immunopositive cells and membrane staining pattern), and mRNA studies have shown the expression of three subtypes of SSTR in human prolactinomas: SSTR1, 2 and 5. The level of expression is highly variable depending on the tumor, but all studies found higher SSTR5 expression followed by lower and variable levels of expression of SSTR2A and SSTR1 [4-6]. The expression pattern has never been associated with DA resistance, tumor size or aggressiveness [5].

A role for SSTRs in prolactin secretion is suspected. However, results from in vitro studies on use of somatostatin analogs in prolactinomas are inconsistent. In some studies, octreotide significantly reduced prolactin secretion of primary human prolactinoma and mixed growth hormone and prolactin (GH-PRL)-secreting cultured cells [7,8]. Other studies showed an uncertain and modest reduction of prolactin secretion and cell viability, especially using octreotide $[6,9,10]$. These inconsistencies could be due to differences in SSTR2 expression, as indicated by Acunzo et al. who observed prolactinomas becoming sensitive to octreotide only after SSTR2 gene transfer [10,11]. Evidence suggests that pasireotide may be more effective 
148 than other somatostatin analogs at reducing prolactin secretion. In 1999, Jaquet et al. 149 demonstrated that another somatostatin agonist (BIM-23268) with high affinity for SSTR 5 150 could inhibit prolactin release from human prolactinomas in primary culture. This 26 to $90 \%$ 151 reduction was higher compared to the one induced by octreotide [5]. More recently, 152 pasireotide and octreotide effects on human prolactinoma and GH/PRL-secreting tumor were 153 compared in vitro. Pasireotide could reduce PRL secretion between 38 and $74 \%$ in GH/PRL 154 and between 23 and $80 \%$ in PRL tumors, compared to the reduction achieved with octreotide 155 of between 16 and $66 \%$ in GH/PRL and 0 and 30\% in PRL tumors [7]. An in vivo study in mouse GH/PRL adenomas then showed not only a greater reduction in prolactin secretion 157 with pasireotide compared to with octreotide but also a superior anti-tumor effect [12]. 158 However, the effects of pasireotide did not differ significantly from octreotide in other recent 159 studies [6,8,9]. Moreover, in these latter studies, the effect of somatostatin analogs on 160 prolactin secretion was weaker than that of DAs, even in prolactinomas considered as 161 resistant [5-7].

As suggested by in vitro studies, the SSTR profile of prolactinomas may explain the 163 mainly disappointing results of first generation somatostatin analogs in treating 164 prolactinomas. Only one successful case of octreotide treatment has been reported [13] in a 165 young man who had previously undergone two surgical excisions. Initiation of octreotide at $20 \mathrm{mg}$ every 28 days in association with cabergoline led to normalized plasma prolactin levels 167 at the 12 month follow-up and stability of the pituitary tumor at 2 years, as shown by MRI. 168 All other studies using cyclic synthetic somatostatins or octreotide reported therapeutic 169 failures [14].

170 Clinical effects of the second-generation somatostatin analog pasireotide on 171 prolactinomas have not yet been reported in the literature. Our report demonstrates the 172 efficacy of pasireotide to normalize prolactin secretion, achieve long-term control over tumor 
173 volume and restore the menstrual cycle in a woman with a resistant prolactinoma ineffectively

174 treated over the previous 24 years with high doses of all available dopamine agonists

175 (bromocriptine, quinagolide, cabergoline). In such cases of DA-resistant prolactinoma, this

176 treatment could be proposed before considering radiotherapy or temozolomide treatment

177 options.

178 No significant adverse effects of pasireotide were observed in this patient. Digestive disorders

179 and hyperglycemia are usually the most frequent adverse effects of this drug. As pasireotide is

180 associated with a reduction in the secretion of the hormones insulin and incretin,

181 hyperglycemia and diabetes are observed in $30 \%$ of acromegalic patients and up to $70 \%$ of

182 patients with Cushing' disease. However, the glucose tolerance disturbance induced by the

183 IGF1 and cortisol excess likely potentiates the hyperglycemia occurring under pasireotide. A

184 lower rate of hyperglycemia events should be expected in patients with prolactinoma.

185 In acromegalic patients, the relation between SSTR subtypes expression by

186 immunohistochemistry and response to somatostatin analogs is suggested $[15,16]$. Our results

187 support this hypothesis in prolactinomas for which SSTR5 expression is significant. SSTR

188 subtype expression profile could therefore potentially guide therapeutic choice and allow a

189 personalized therapy for these rare patients.

190 In conclusion, our case has demonstrated the potential role of pasireotide for treating DA-

191 resistant macroprolactinomas. SSTR expression may guide the choice of therapy. However,

192 pasireotide being quickly efficient, administration as a short therapeutic test may be sufficient

193 to identify potential responders. 


\section{Patient consent}

198 The author confirm that informed consent has been obtained from the patient for publication

199 of the case report and accompanying images.

200

\section{Funding}

202 This research did not receive any specific grant from any funding agency in the public,

203 commercial or not-for-profit sector.

204

205 Acknowledgements:

206 The manuscript has been revised for the English by an independent scientific language editing 207 service, Angloscribe.

208

\section{Disclosure summary}

210 The authors declare that they have no competing interest.

211

212 
214 [1] Di Sarno A, Landi ML, Cappabianca P, Di Salle F, Rossi FW, Pivonello R, et al. prevalence, clinical definition, and therapeutic strategy. J Clin Endocrinol Metab 2001;86:5256-61. doi:10.1210/jcem.86.11.8054.

[2] Vroonen L, Jaffrain-Rea M-L, Petrossians P, Tamagno G, Chanson P, Vilar L, et al. Prolactinomas resistant to standard doses of cabergoline: a multicenter study of 92 patients. Eur J Endocrinol 2012;167:651-62. doi:10.1530/EJE-12-0236.

[3] Bruns C, Lewis I, Briner U, Meno-Tetang G, Weckbecker G. SOM230: a novel somatostatin peptidomimetic with broad somatotropin release inhibiting factor (SRIF) receptor binding and a unique antisecretory profile. Eur J Endocrinol 2002;146:707-16.

[4] Thodou E, Kontogeorgos G, Theodossiou D, Pateraki M. Mapping of somatostatin receptor types in $\mathrm{GH}$ or/and PRL producing pituitary adenomas. J Clin Pathol 2006;59:274-9. doi:10.1136/jcp.2005.026914.

[5] Jaquet P, Ouafik L, Saveanu A, Gunz G, Fina F, Dufour H, et al. Quantitative and functional expression of somatostatin receptor subtypes in human prolactinomas. J Clin Endocrinol Metab 1999;84:3268-76. doi:10.1210/jcem.84.9.5962.

[6] Fusco A, Gunz G, Jaquet P, Dufour H, Germanetti AL, Culler MD, et al. Somatostatinergic ligands in dopamine-sensitive and -resistant prolactinomas. Eur $\mathbf{J}$ Endocrinol 2008;158:595-603. doi:10.1530/EJE-07-0806.

[7] Hofland LJ, van der Hoek J, van Koetsveld PM, de Herder WW, Waaijers M, SprijMooij D, et al. The novel somatostatin analog SOM230 is a potent inhibitor of hormone release by growth hormone- and prolactin-secreting pituitary adenomas in vitro. J Clin Endocrinol Metab 2004;89:1577-85. doi:10.1210/jc.2003-031344.

[8] Murray RD, Kim K, Ren S-G, Lewis I, Weckbecker G, Bruns C, et al. The novel somatostatin ligand (SOM230) regulates human and rat anterior pituitary hormone secretion. J Clin Endocrinol Metab 2004;89:3027-32. doi:10.1210/jc.2003-031319.

[9] Ibáñez-Costa A, Rivero-Cortés E, Vázquez-Borrego MC, Gahete MD, Jiménez-Reina L, Venegas-Moreno E, et al. Octreotide and pasireotide (dis)similarly inhibit pituitary tumor cells in vitro. J Endocrinol 2016;231:135-45. doi:10.1530/JOE-16-0332.

[10] Cuny T, Mohamed A, Graillon T, Roche C, Defilles C, Germanetti A-L, et al. Somatostatin receptor sst2 gene transfer in human prolactinomas in vitro: impact on sensitivity to dopamine, somatostatin and dopastatin, in the control of prolactin secretion. Mol Cell Endocrinol 2012;355:106-13. doi:10.1016/j.mce.2012.01.026.

[11] Acunzo J, Thirion S, Roche C, Saveanu A, Gunz G, Germanetti AL, et al. Somatostatin receptor sst2 decreases cell viability and hormonal hypersecretion and reverses octreotide resistance of human pituitary adenomas. Cancer Res 2008;68:10163-70. doi:10.1158/0008-5472.CAN-08-1857.

[12] Fedele M, De Martino I, Pivonello R, Ciarmiello A, Del Basso De Caro ML, Visone R, et al. SOM230, a new somatostatin analogue, is highly effective in the therapy of growth hormone/prolactin-secreting pituitary adenomas. Clin Cancer Res Off J Am Assoc Cancer Res 2007;13:2738-44. doi:10.1158/1078-0432.CCR-06-2505.

[13] Fusco A, Lugli F, Sacco E, Tilaro L, Bianchi A, Angelini F, et al. Efficacy of the combined cabergoline and octreotide treatment in a case of a dopamine-agonist resistant macroprolactinoma. Pituitary 2011;14:351-7. doi:10.1007/s11102-008-0162-y.

[14] Bronstein MD, Knoepfelmacher M, Liberman B, Marino R, Germek OA, Schally AV. Absence of suppressive effect of somatostatin on prolactin levels in patients with hyperprolactinemia. Horm Metab Res Horm Stoffwechselforschung Horm Metab 1987;19:271-4. doi:10.1055/s-2007-1011796. 
[15] Iacovazzo D, Carlsen E, Lugli F, Chiloiro S, Piacentini S, Bianchi A, et al. Factors predicting pasireotide responsiveness in somatotroph pituitary adenomas resistant to first-generation somatostatin analogues: an immunohistochemical study. Eur $\mathbf{J}$ Endocrinol 2016;174:241-50. doi:10.1530/EJE-15-0832.

[16] Plöckinger U, Albrecht S, Mawrin C, Saeger W, Buchfelder M, Petersenn S, et al. Selective loss of somatostatin receptor 2 in octreotide-resistant growth hormonesecreting adenomas. J Clin Endocrinol Metab 2008;93:1203-10. doi:10.1210/jc.20071986. 


\section{Figures legends:}

273 Figure 1: Histopathological features of the first surgical specimen (original magnification $\mathrm{x}$ $274 \quad 400)$

275 A- On hematoxylin phloxine saffron staining, the tumor shows a diffuse growth pattern. 276 Anisokaryosis is moderate and numerous nuclei show a prominent nucleolus.

277 B- The majority of neoplastic cells show typical paranuclear prolactin immunoreactivity.

278 C- A moderately intense membranous immunoexpression of SSTR5 is observed in 25\% of 279 neoplastic cells.

280 D- Only 5\% of neoplastic cells show a membranous immunopositivity for SSTR2.

282 Figure 2: Prolactin levels and MRI evolution (four years before pasireotide initiation (2006), 283 at pasireotide initiation (2010-MO), at 3 months after pasireotide initiation (2010-M3) and at 284 the last follow-up (2017)). 

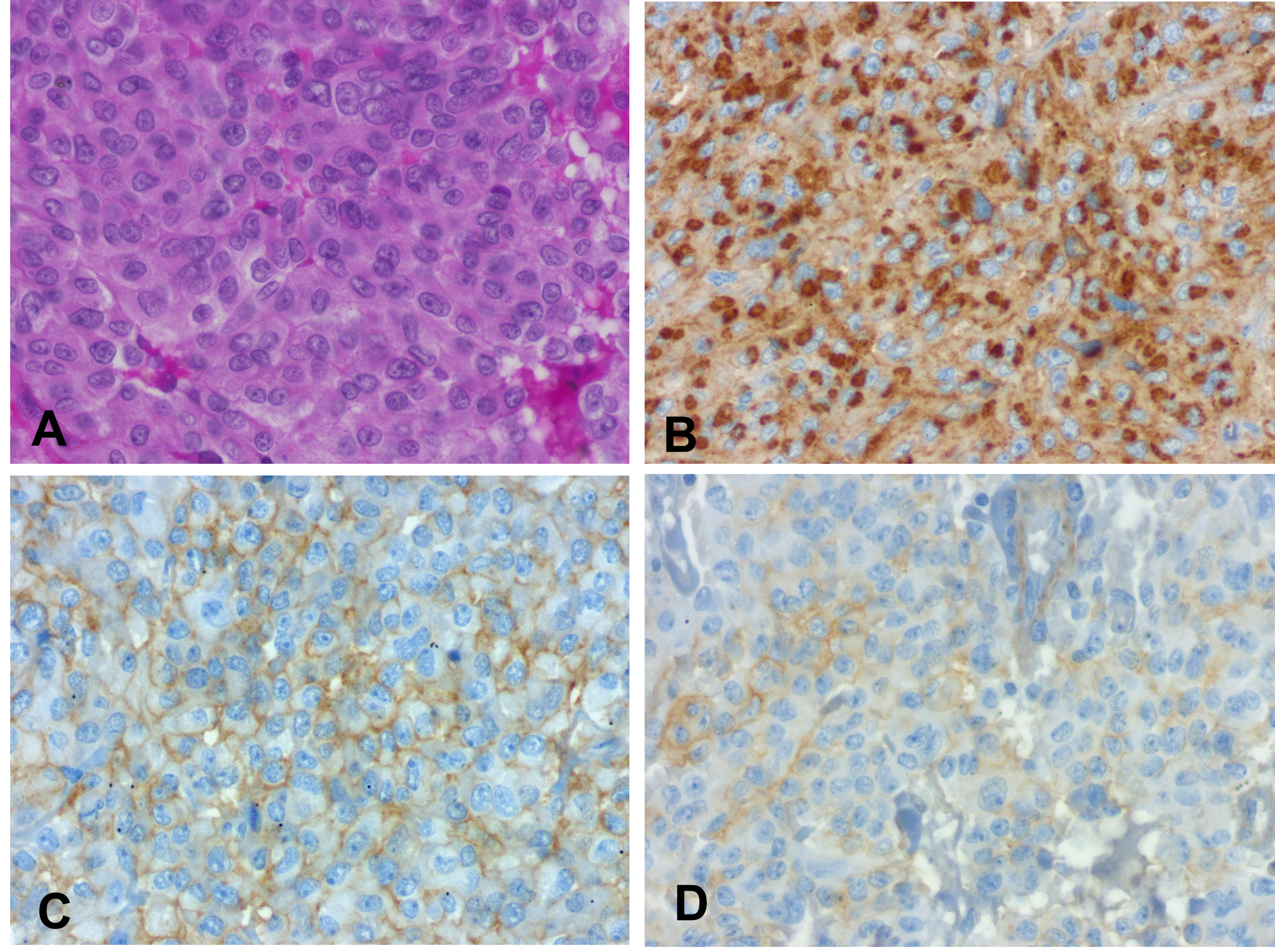


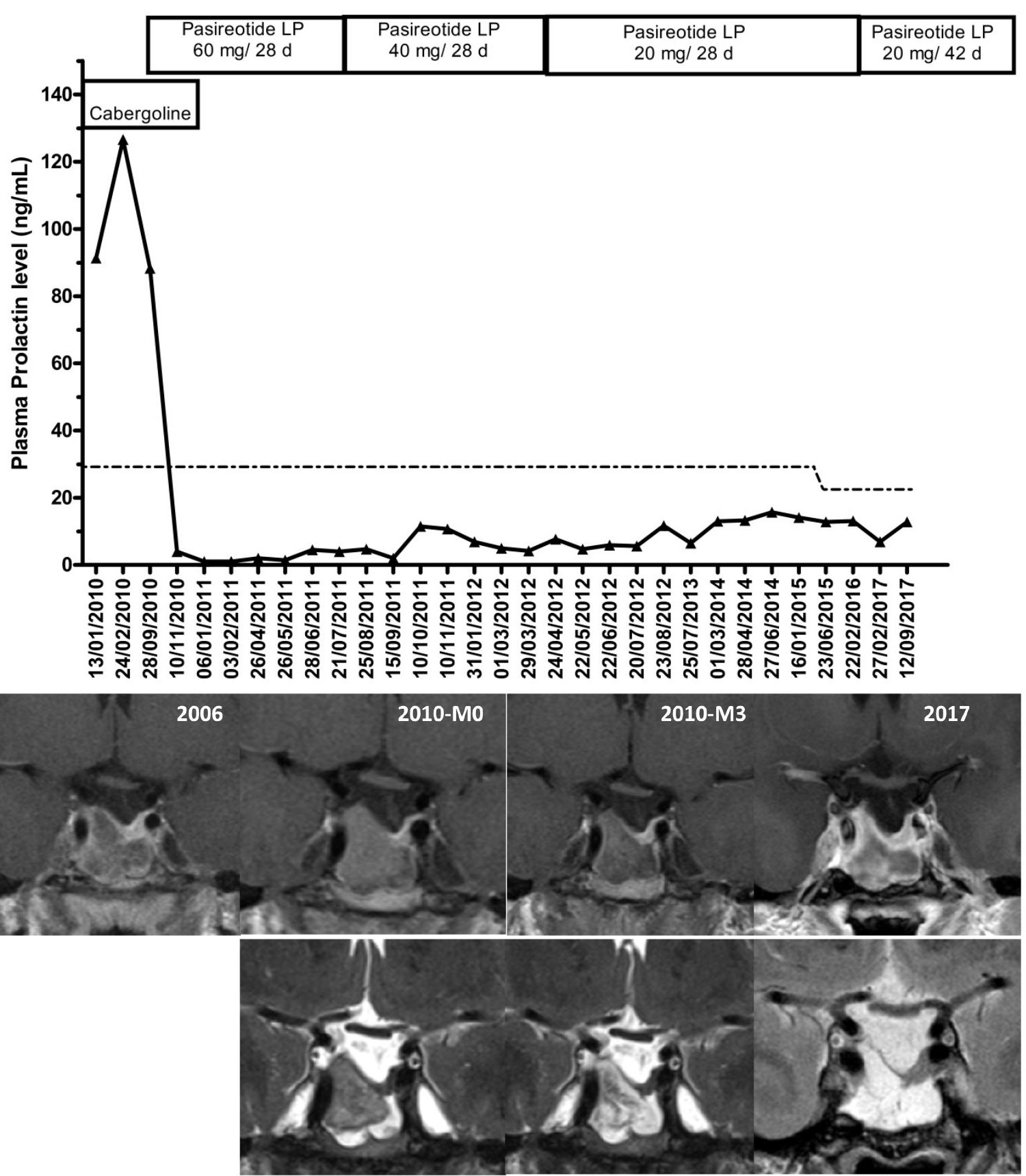

